НАУКОВИЙ ВІСНИК

(1)

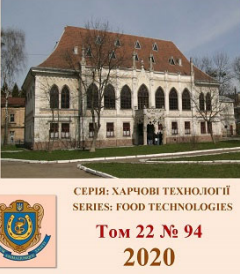

\section{Науковий вісник Яьвівського національного університету} ветеринарної медицини та біотехнологій імені С.3. Гжицького.

Серія: Харчові технології

\section{Scientific Messenger of Lviv National University of Veterinary Medicine and Biotechnologies.}

Series: Food Technologies

ISSN 2519-268X print

ISSN $2707-5885$ online doi: 10.32718/nvlvet-f9402

https://nvlvet.com.ua/index.php/food

UDC 636.09:001.893:[57.083.32;613.26/28:577.2]

\title{
Monitoring of gluten in dairy products
}

\author{
O. Haidei ${ }^{1}$, S. Shuliak ${ }^{1}$, I. Oleksiienko ${ }^{1}$, G. Kyivska ${ }^{1}$, O. Krushelnytska ${ }^{2}$
}

${ }^{I}$ State Scientific and Research Institute of Laboratory Diagnostics and Veterinary and Sanitary Expertise, Kyiv, Ukraine

${ }^{2}$ Stepan Gzhytskyi National University of Veterinary Medicine and Biotechnologies Lviv, Ukraine

Article info

Received 28.08.2020

Received in revised form 29.09.2020

Accepted 30.09.2020

State Scientific and Research Institute of Laboratory Diagnostics And Veterinary and Sanitary Expertise, Donetska Str., 30, Kyiv, 03151, Ukraine. Tel.: +38-067-171-15-58 E-mail: olga.gaidei@gmail.com

Stepan Gzhytskyi National University of Veterinary Medicine and Biotechnologies Lviv, Pekarska Str., 50, Lviv, 79010, Ukraine.
Haidei, O., Shuliak, S., Oleksiienko, I., Kyivska, G., \& Krushelnytska, O. (2020). Monitoring of gluten in dairy products. Scientific Messenger of Lviv National University of Veterinary Medicine and Biotechnologies. Series: Food Technologies, 22(94), 8-12. doi: 10.32718/nvlvetf9402

According to the World Gastroenterology Organization, the prevalence of celiac disease in the world is estimated at 1 in 300 people. According to unofficial statistics of the Celiac Disease Union, about 400,000 Ukrainian citizens have an individual intolerance to gluten. Given the large number of people with individual gluten intolerance and its only treatment - a lifelong diet, there is a need to monitor gluten in food, namely in dairy products. As not all manufacturers adhere to the HACCP system in good faith in their production, there is a risk of gluten entering the finished product. The aim of the study was to evaluate dairy products for gluten content. The article presents information on the results of monitoring gluten in dairy products (butter, margarine, kefir, sour milk cheeses, yogurt, hard and soft cheeses) producers of different regions of Ukraine by molecular genetic method in 2018-2020 using diagnostic R-Biopharm kits. According to research, it was found that $17 \%$ of dairy products do not contain gluten, $83 \%$ contain from 2 to $5 \mathrm{mg} / \mathrm{kg}$; $37.5 \%$ of hard and soft cheeses, sweet cream butter, margarine do not contain gluten; $62.5 \%$ contain gluten in the amount of 2 to $5 \mathrm{mg} / \mathrm{kg}$, which is within acceptable limits for people with celiac disease. Studies have shown that a significant percentage of dairy products contain from 2 to $5 \mathrm{mg} \mathrm{kg}$ of gluten, which may indicate accidental entry into the final product or technical contamination. However, although these products are not certified as gluten-free and meet the requirements of current legislation. A significant range of products with a gluten content of up to $5 \mathrm{mg} / \mathrm{kg}$ encourages the implementation of the Gluten Control (Monitoring) Program in all products to increase the range for people with individual needs. Prospects for further research are to monitor meat products, semi-finished products, dietary products, baby food of domestic production for further analysis of compliance with current legislation and safety for people with individual intolerance to gluten.

Key words: food allergens, gluten, gluten intolerance, celiac disease, monitoring, PCR, milk products.

\section{Моніторинг глютену в молочній продукції}

\author{
О. С. Гайдей${ }^{1}$, С. В. Шуляк ${ }^{1}$ І І. С. Олексієнко ${ }^{1}$, Г. В. Київська ${ }^{1}$, О. В. Крушельницька ${ }^{2}$
}

${ }^{1}$ Державний науково-дослідний інститут з лабораторної діагностики та ветеринарно-санітарної експертизи, м. Київ, Украӥна

${ }^{2}$ Львівський національний університет ветеринарної медицини та біотехнологій імені С. 3. Гжицького, м. Львів, Украӥна

За даними Всесвітньої гастроентерологічної організачії, поширеність иеліакії у світі оичнюється як 1 на 300 осіб. За неофіційною статистикою ВГО “Спілка целіакії”, індивідуальне несприйняття глютену мають близько 400 тис. громадян Украӥни. Враховуючи значну кількість осіб з індивідуальним несприйняттям глютену та єдине лікування його - пожиттєву дієту, виникла необхідність провести моніторинг глютену в харчових продуктах, а саме в молочній продукиії. Оскільки не всі виробники сумлінно дотримуються системи НАССР на своїх виробництвах, існує ризик потрапляння глютену в готовий продукт. Метою досліджень було оцінити молочну продукиію на предмет вмісту глютену. В статті наведена інформація шуодо результатів моніторингу 
глютену в молочних продуктах (вершкове масло, маргарин, кефір, кисломолочні сири, йогурт, тверді та м'які сири) виробників різних регіонів України молекулярно-генетичним методом у 2018-2020 рр. з використанням діагностичних наборів R-Bіорһагт. 3a результатами досліджень встановлено, шо 17 \% кисломолочних продуктів не містить глютену, 83 \% містять від 2 до 5 мг/кг; 37,5 \% твердих та м'яких сирів, масла солодковершкового, маргарину не містять глютену; 62,5 \% містять глютен у кількості від 2 до 5 мг/кг, шо є в межах допустимих норм для людей з иеліакією. Проведені дослідження показали, ияо значний відсоток молочних продуктів містить від 2 до 5 мг/кг глютену, щуо може свідчити про випадкове потрапляння його у кінцевий продукт або технічну контамінацію. Проте дана продукиія хоч і не сертифікована як безглютенова, та відповідає вимогам чинного законодавства. Значний асортимент продукиії з вмістом глютену до 5 мг/кг спонукає до впровадження Програми контролю (моніторингу) глютену у всіх продуктах для збільшення асортименту для людей з індивідуальними потребами. Перспективами подальших досліджень є проведення моніторингу м'ясних продуктів, напівфабрикатів, дієтичних продуктів, дитячого харчування вітчизняного виробництва для подальшого аналізу відповідності чинному законодавству та безпечності для людей з індивідуальним несприйняттям глютену.

Ключові слова: харчові алергени, глютен, целіакія, моніторинг, ПЛР, молочні продукти.

\section{Встуі}

Число людей, які страждають на целіакію та несприйняття глютену в Україні, за даними вітчизняних дослідників, наближається до 400 тисяч осіб; 47,5 тис. дітей мають розлад аутичного спектра, 19,69 тисяч страждають від дитячого церебрального паралічу, діагноз “целіакія" встановлено в 2500 пацієнтів (Kraievska \& Stetsenko, 2018; World Gastroenterology Organization Global Guidelines; Association of European Coeliac Societies). Проте значна кількість людей взагалі не підозрюють про наявність даної недуги, оскільки не проводили діагностики. Недіагностована целіакія може призвести до серйозних наслідків, таких як злоякісні захворювання шлунко-кишкового тракту - лімфома тонкого кишківника, безпліддя, остеопороз, відставання в рості та розвитку, аутоімунні захворювання, які виникають в 10 разів частіше у дорослих пацієнтів 3 целіакією. Смертність серед хворих 3 глютеновою ентеропатією становить 10 $30 \%$, тимчасом як при адекватному лікуванні - суворій безглютеновій дієті - вона знижується до $0,4 \%$. Для таких людей важливо дотримуватися пожиттєвої дієти та володіти інформацією щодо вмісту глютену в харчових продуктах (Bai et al., 2005; Roslavceva, 2005; Bel'mer \& Gasilina, 2013; Kamalova \& Pirogova, 2013). Відповідно до міжнародного стандарту, встановленого Codex Alimentarius, продовольчі продукти, в яких вміст глютену не перевищує 20 мг/кг в загальній масі харчового продукту, можуть маркуватися “без глютену”. Використання маркування “без глютену” дозволено Регламентом ЄС № 41/2009, який застосовується до харчових продуктів, що вироблені для людей, які не сприймають клейковини. Регламент Комісії $\mathrm{CC}$ застосовується до всіх харчових продуктів (включаючи алкоголь, харчові добавки тощо) в пакуванні та без нього, крім дитячих сумішей (Babich \& Vikhot, 2016; Association of European Coeliac Societies; Gluten Free Media Group).

Гарантією безпеки безглютенового продукту є міжнародно визнаний символ "Перекреслений колосок”, який пропагується об'єднаннями хворих на целіакію. В Європі сертифікуючим органом є AOECS некомерційна організація, що об'єднує 37 європейських національних громадських організацій хворих на целіакію. Її ліцензійний символ - перекреслений колосок, використання якого надається компаніям, чия продукція відповідає вимогам AOECS до безглютенових продуктів харчування і означає безпеку цих про- дуктів для споживачів. Станом на травень 2020 р. виробники - члени AOECS отримали ліцензію на 22000 продуктів без глютену в усій Свропі (Kraievska \& Stetsenko, 2018).

Кожен ліцензований продукт пройшов тестування в акредитованій лабораторії. Щороку підприємство перевіряється, щоб забезпечити послідовне виробництво безглютенової продукції (Kraievska \& Stetsenko, 2018; Grand Vew Research, 2020).

Досить тривалий час в Україні не було жодного нормативного документа, який би регламентував маркування глютену та інших алергенів у харчових продуктах. Лише 06.12.2018 р. 3 прийняттям Закону України № 2639-VIII “Про інформацію для споживачів щодо харчових продуктів” врегулювалося питання маркування глютену та інших алергенів в України. Стаття 15 даного Закону передбачає, що назва речовини або харчового продукту, що спричиняють алергічні реакції або несприйняття, має бути виділена (шрифтом, кольоровим фоном, стилем тощо) серед решти інгредієнтів у переліку інгредієнтів у спосіб, визначений оператором ринку харчових продуктів, відповідальним за інформацію про харчовий продукт. Позначення “без глютену" може бути застосовано лише за умови, що вміст глютену у харчових продуктах, що пропонуються до реалізації кінцевому споживачеві, не перевищує 20 мг/кг загальної маси харчового продукту (Zakon Ukrainy № 2639-VIII, 2018).

На сьогодні маркування більшості вітчизняних харчових продуктів взагалі не містить інформації щодо наявності глютену та інших алергенів. Враховуючи вищезазначене, виникла необхідність моніторингу глютену в харчових продуктах.

Мета $і$ завдання дослідження: провести моніторинг глютену в молочній продукції, проаналізувати результати досліджень на відповідність чинному законодавству.

\section{Матеріал і методи досліджень}

Дослідження молочної продукції проводилися протягом 2018-2020 рр. в лабораторії молекулярногенетичних-досліджень харчової безпеки ДНДІЛДВСЕ методом ПЛР-РЧ з використанням діагностичних тест-систем для ДНК-екстракції SureFood Prep Advanced, R-Biopharm; діагностичного набору для виявлення та кількісного визначення глютену SureFood Allergen Gluten, R-Biopharm 3 межею виявлення 0,4 мг/кг та межею кількісного визначення 
1 мг/кг; референс-матеріалу SureFood Quantard Allergens 40, R-Biopharm 3 концентрацією глютену 40 мг/кг. Термоциклер Thermo Fisher Scientific QuantStudio5. Об'єкт випробувань: молочна продукція різних виробників, які не сертифіковані як виробники безглютенової продукції: вершкове масло, кефір, йогурт, кисломолочні сири, тверді та м'які сири.

\section{Таблиця 1}

Результати моніторингу глютену в кисломолочних продуктах

\begin{tabular}{|c|c|c|c|}
\hline № ח/П & Назва продукту & Регіон-виробник & Вміст глютену, мг/кг (ppm) \\
\hline \multirow{4}{*}{1} & \multirow{4}{*}{ Keфip 2,5\% } & Миколаївська обл. & 2 \\
\hline & & Дніпропетровська обл. & 2 \\
\hline & & Київська обл. & 5 \\
\hline & & Полтавська обл. & 2 \\
\hline \multirow{9}{*}{2} & \multirow{9}{*}{$\begin{array}{l}\text { Йогурт питний 2,5 \% } 3 \text { фрукто- } \\
\text { вим наповнювачем }\end{array}$} & Київська обл. & 2 \\
\hline & & Київська обл. & 2 \\
\hline & & Львівська обл. & не містить глютену \\
\hline & & Київська обл. & не містить глютену \\
\hline & & Дніпропетровська обл. & 5 \\
\hline & & Запорізька обл. & 2 \\
\hline & & Київська обл. & 2 \\
\hline & & Київська обл. & 3 \\
\hline & & Київська обл. & не містить глютену \\
\hline \multirow{3}{*}{3} & \multirow{3}{*}{ Сир кисломолочний нежирний } & Харківська обл. & 3 \\
\hline & & Київська обл. & 2 \\
\hline & & Київська обл. & не містить глютену \\
\hline \multirow{2}{*}{4} & \multirow{2}{*}{$\begin{array}{l}\text { Сир кисломолочний зернистий } \\
5 \%\end{array}$} & Київська обл. & 2 \\
\hline & & Миколаївська обл. & 2 \\
\hline \multirow{3}{*}{5} & \multirow{3}{*}{ Сир кисломолочий 9 \% } & Київська обл. & не містить глютену \\
\hline & & Київська обл. & 2 \\
\hline & & Київська обл. & 5 \\
\hline \multirow{4}{*}{6} & \multirow{4}{*}{$\begin{array}{l}\text { Сирок глазурований в шоколаді } \\
15 \%\end{array}$} & Київська обл. & 2 \\
\hline & & Дніпропетровська обл. & 2 \\
\hline & & Миколаївська обл. & 2 \\
\hline & & Харківська обл. & 2 \\
\hline
\end{tabular}

Результати проведених досліджень показали, що 25 зразків (17\%) кисломолочних продуктів (йогурт питний (Львівська, Київська обл.), сир кисломолочний нежирний (Київська обл.) не містять глютену. Решта 100 зразків (83\%) містять глютен у незначній кількості - від 2 до 5 мг/кг, що є допустимою нормою для людей з целіакією (рис. 1).

Другою групою молочних продуктів для досліджень були тверді та м'які сири, масло солодковершкове, маргарин різних виробників, серед яких 45 зразків (37,5 \%) не містять глютену (сир “Голланд-

\section{Результати та їх обговорення}

За період 2018-2020 рр. у продуктових мережах України були відібрано 245 зразків молочних продуктів різних виробників з Київської, Полтавської, Миколаївської, Дніпропетровської, Львівської, Запорізької, Одеської, Хмельницької, Харківської, Луганської, Сумської, Рівненської, Тернопільської областей. Відбирали зразки різних торгових марок у кількості по 5 одиниць (табл. 1, 2). Дослідження 3 визначення глютену проводилися методом полімеразно-ланцюгової реакції у режимі реального часу. ський” (Рівненська обл.); сир сичужний "Моцарела" (Київська, Полтавська обл.), сир м'який “Адигейський” (Дніпропетровська, Київська обл.), сир м'який “Фета” (Київська обл.), масло солодковершкове (Полтавська обл.), маргарин столовий (Київська обл.); 75 зразків (62,5 \%) містять глютен у кількості від 2 до 5 мг/кг (рис. 2), що є допустимими значеннями для людей з целіакією (рис. 1).

Наявність глютену в молочних продуктах може свідчити про випадкове його потрапляння у продукт та недостатню обробку технологічних ліній. 


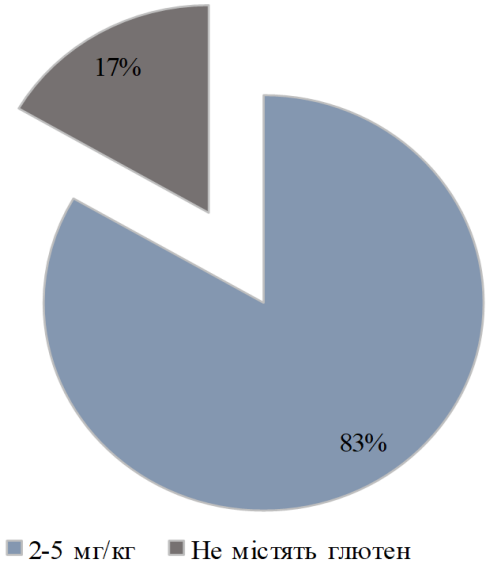

Рис. 1. Результати дослідження глютену в кисломолочних продуктах, \%

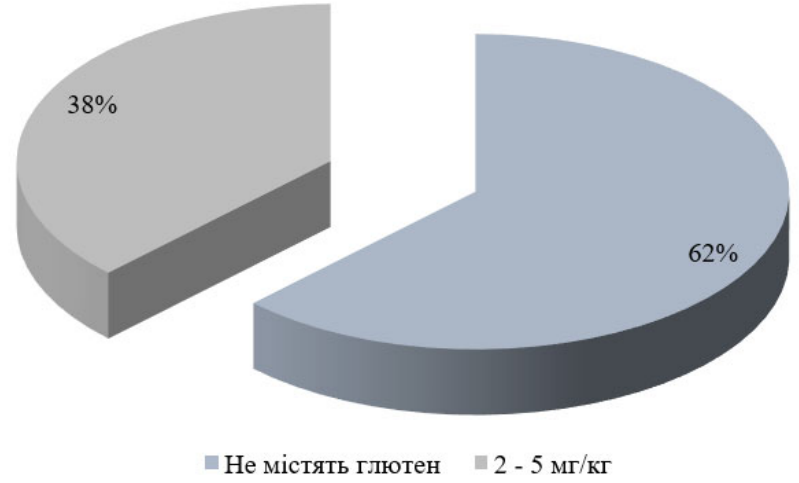

Рис. 2. Результати дослідження глютену в твердих і м'яких сирах, маслі солодковершковому, маргарині, \%

Таблиця 2

Результати моніторингу глютену в твердих та м'яких сирах, маслі вершковому, маргарині

\begin{tabular}{|c|c|c|c|}
\hline № ח/п & Назва продукту & Регіон-виробник & Вміст глютену, мг/кг (ppm) \\
\hline \multirow[b]{2}{*}{1} & \multirow{2}{*}{ Сир плавлений 55 \% } & Київська обл. & 2 \\
\hline & & Миколаївська обл. & 2 \\
\hline \multirow{4}{*}{2} & \multirow{4}{*}{ Сир “Російський” 50 \% } & Сумська обл. & 5 \\
\hline & & Луганська обл. & 2 \\
\hline & & Миколаївська обл. & 2 \\
\hline & & Полтавська обл. & 3 \\
\hline \multirow{4}{*}{3} & \multirow{4}{*}{ Сир “Голландський” } & Миколаївська обл. & 2 \\
\hline & & Київська обл. & 2 \\
\hline & & Рівненська обл. & не містить глютену \\
\hline & & Тернопільська обл. & 2 \\
\hline \multirow{2}{*}{4} & \multirow{2}{*}{$\begin{array}{l}\text { Сир сичужний “Моцарелла" } \\
45 \%\end{array}$} & Київська обл. & не містить глютену \\
\hline & & Полтавська обл. & не містить глютену \\
\hline 5 & Сир м’який “Адигейський” & Дніпропетровська обл. & не містить глютену \\
\hline \multirow{2}{*}{6} & \multirow{2}{*}{ Сир м’який “Фета” 45 \% } & Київська обл. & 2 \\
\hline & & Київська обл. & не містить глютену \\
\hline \multirow{6}{*}{7} & \multirow{6}{*}{$\begin{array}{l}\text { Масло солодковершкове } \\
82,5 \%\end{array}$} & Миколаївська обл. & 2 \\
\hline & & Хмельницька обл. & 2 \\
\hline & & Дніпропетровська обл. & 2 \\
\hline & & Одеська обл. & 2 \\
\hline & & Полтавська обл. & не містить глютену \\
\hline & & Київська обл. & 2 \\
\hline \multirow[t]{2}{*}{8} & \multirow[t]{2}{*}{ Маргарин столовий } & $\begin{array}{l}\text { Київська обл. } \\
\text { Київська обл }\end{array}$ & не містить глютену \\
\hline & & Київська обл. & \\
\hline
\end{tabular}

\section{Висновки}

Результати проведених досліджень свідчать про те, що молочна продукція, що не маркована як “без глютену”, відповідала вимогам чинного законодавства України та Регламенту ЄС № 41/2009 стосовно безглютенової продукції. Враховуючи асортимент продуктів з вмістом глютену до 5 мг/кг, виникає необхідність створення Програми державного контролю глютену у всій харчовій продукції та аналізу ризиків, що дасть доступ споживачам з целіакією до більшого асортименту харчових продуктів.

Перспективи подальших досліджень. Провести моніторинг глютену у м'ясній продукції та напівфаб- рикатах, солодощах, дієтичних продуктах вітчизняного виробництва та проаналізувати результати проведених досліджень на відповідність чинному законодавству.

\section{References}

Association of European Coeliac Societies (AOECS). Retrieved from www.aoecs.org.

Babich, O. V., \& Vikhot, M. M. (2016). Problematyka zabezpechennia spetsialnymy produktamy kharchuvannia khvorykh na tseliakiiu v Ukraini. Problemy starinnia i dovholittia, 25(2), 230-234. 
URL: http://nbuv.gov.ua/UJRN/PSD_2016_25_2_7 (in Ukrainian).

Bai, J., Zeballos, E., Fried, M., et al. (2005). Practice Guideline Celiac Disease. WGO-OMGE, 10, 1-8.

Bel'mer, S. V., \& Gasilina, T. V. (2013). Celiakija: ot patogeneza $\mathrm{k}$ lecheniju. Voprosy sovremennoj pediatrii, 12(3), 12-17. doi: 10.15690/vsp.v12i3.676 (in Russian).

Gluten Free Media Group. Retrieved from http://www.glutenfreemg.com.

Grand Vew Research (2020). Gluten-Free Products Market Analysis By Product (Bakery, Dairy Alternatives, Desserts \& Ice-Creams, Prepared Foods, Pasta \& Rice), By Distribution (Grocery Stores, Mass Merchandiser, Club Stores), And Segment Forecasts, 2018-2025. Retrieved from https://www.grandviewresearch.com/industryanalysis/gluten-free-products-market.

Kamalova, A. A., \& Pirogova, M. O. (2013). Jevoljucija podhodov $\mathrm{k}$ diagnostike i terapii celiakii. Vestnik sov- remennoj klinicheskoj mediciny, 6(3), 40-48. URL: https://cyberleninka.ru/article/n/evolyutsiya-podhodovk-diagnostike-i-terapii-tseliakii/viewer (in Russian).

Kraievska, S., \& Stetsenko, N. (2018). Formuvannia vitchyznianoho rynku bezghliutenovykh produktiv. Tovary i rynky, 4, 36-46. URL: http://nbuv.gov.ua/UJRN/tovary_2018_4_6 (in Ukrainian).

Roslavceva, E. A. (2005). Celiakija: nereshennye problemy patogeneza, diagnostiki i lechenija. Voprosy sovremennoj pediatrii, 4(6), 48-57 (in Russian).

World Gastroenterology Organization Global Guidelines [World Gastroenterology Organization Global Guidelines]. URL: http://www.worldgastroenterology.org/ global-guidelines.html.

Zakon Ukrainy № 2639-VIII vid 06.12.2018 "Pro informatsiiu dlia spozhyvachiv shchodo kharchovykh produktiv". URL: https://zakon.rada.gov.ua/laws/show/263919\#Text (in Ukrainian). 